\title{
Analisis Faktor-Faktor Yang Menyumbang Kepada Penglibatan Politik Dalam Kalangan Penduduk Pulau Pinang
}

\author{
Noor Atirah Eliya Mohd Nor, Hasrina Mustafa* \\ Pusat Pengajian Komunikasi, Universiti Sains Malaysia, 11800 Pulau Pinang \\ *Corresponding author: hasrina@usm.my
}

\begin{abstract}
Political participation is one of the fundamental principles of democracy, without which any nation with such system will cease to exist. There are many factors influencing political participation of an individual in a country. Hence this research aims to understand the influence of the level of media usage (i.e. television, radio, newspaper and internet), interest, attitude, general knowledge towards politics and age on political participation through the mediating role of interpersonal discussion, utilizing the Differential Gains Model. A survey involving 386 registered voters in Penang, Malaysia was conducted. The survey discovered that interest in and general knowledge on politics significantly influenced the level of the respondents' political participation. None of any media factors, attitudes toward politics and age was found to affect political participation. Consistent with the Model of Differential Gains, interpersonal discussion on politics significantly mediated the relationships between level of media usage (namely radio and newspaper) and general knowledge on politics; and political participation. The study summarised that interpersonal discussion on political issues with friends and family members is more vital to increase people's involvement in local politics as compared to mass media.
\end{abstract}

Keyword: Differential Gain Model, Interpersonal discussion, mass media usage, political participation

\section{Abstrak}

Penglibatan politik adalah antara asas fundamental dalam sistem demokrasi, tanpanya sesebuah negara berteraskan sistem tersebut akan berkubur. Terdapat pelbagai faktor yang mempengaruhi penglibatan politik seseorang individu dalam sesebuah negara. Justeru itu tujuan kajian ini adalah untuk meneliti kesan penggunaan media massa (iaitu televisyen, radio, surat khabar, Internet), minat, sikap, pengetahuan umum terhadap politik serta umur yang mempengaruhi penglibatan politik seseorang individu melalui perantaraan faktor perbincangan interpersonal dengan mengaplikasikan Model Differential Gains. Tinjauan yang melibatkan 386 responden di Pulau Pinang, Malaysia telah dijalankan. Hasil kajian ini mendapati bahawa minat terhadap politik dan pengetahuan umum tentang isu-isu politik paling mempengaruhi tahap penglibatan responden dalam politik. Kesemua faktor pendedahan media massa, sikap terhadap politik dan umur didapati tidak mempengaruhi penglibatan politik. Selaras dengan Model Differential Gains, faktor perbincangan interpersonal tentang politik di dapati berperanan sebagai faktor perantara antara penggunaan media massa (iaitu radio dan surat) dan pengetahuan umum terhadap politik dan penglibatan politik seseorang individu. Kajian merumuskan bahawa perbincangan interpersonal tentang isu politik semasa bersama rakan-rakan dan keluarga sangat penting dalam meningkatkan penglibatan rakyat dalam arus politik tempatan berbanding media massa.

Kata kunci:. Model differential gains, perbincangan interpersonal, penggunaan media massa, penglibatan politik

(C) 2018 Penerbit UTM Press. All rights reserved

\subsection{PENGENALAN}

Penglibatan rakyat sesebuah negara dalam sistem politik negara amat penting bagi menjamin kesejahteraan negara, keharmonian rakyat dan kesahan kerajaan yang dipilih. Dalam sistem demokrasi terutamanya, penglibatan politik secara aktif dalam kalangan rakyat menjadi asas kekukuhan sistem tersebut. Tanpa komitmen, penyertaan yang tinggi dan budaya berpolitik yang murni, sistem demokrasi yang bertunjangkan kebebasan memilih dan bersuara akan lemah dan berkubur.

Setiap warga negara perlu mempunyai kesedaran tentang kepentingan peranan mereka dalam menegakkan sistem politik negara dan kuasa mereka dalam mempengaruhi proses pembuatan keputusan dalam kerajaan, bukan sekadar menjadi pak turut dalam sistem tersebut. Kesedaran ini perlu diterjemahkan dalam bentuk penyertaan, advokasi dan mobilisasi individu dan masyarakat agar prinsip-prinsip asas demokrasi terus bernafas bebas demi kemakmuran masyarakat dan negara.

Konsep penglibatan politik telah lama diperbahaskan (Milbrath, 1965 di dalam Ruedin, 2007; Verba dan Nie, 1972; Huntington dan Nelson, 1976). Kebanyakan perbahasan melihat konsep penglibatan politik sebagai aktiviti fizikal berkaitan pengundian seperti mengundi untuk pilihanraya walaupun konsep politik itu sendiri adalah luas yang merangkumi penglibatan politik dalam konteks badan-badan atau pertubuhan yang berkaitan seperti kesatuan sekerja, kumpulan advokasi dan badan-badan professional. Misalnya Moyes dan Allen (1977) turut melihat penglibatan politik dalam organisasi yang berorientasikan keuntungan dan mendefinasikan politik dalam organisasi sebagai satu bentuk pengurusan pengaruh bagi mencapai matlamat. Malah March (1962) turut merumuskan bahawa setiap organisasi adalah 
sebenarnya satu kesatuan politik di mana keputusan dan matlamat dibentuk melalui proses perundingan antara individu yang mempunyai kuasa.

Walau bagaimanapun, dalam konteks kajian ini, penglibatan politik lebih menjuruskan aktiviti pengundian semasa pilihanraya. Refleksi pemahaman yang sama tentang konsep tersebut dapat dilihat dari kacamata Verba dan Nie (1972: ms 2) yang melihat "penglibatan politik sebagai aktiviti-aktiviti yang dilakukan oleh warganegara yang sama ada secara langsung atau tidak langsung bertujuan mempengaruhi pemilihan wakil-wakil kerajaan serta aktiviti yang diambil mereka". Definisi ini lebih menjurus kepada aktivitiaktiviti yang khusus melibatkan pengundian dalam proses pilihanraya.

Walau bagaimanapun kebanyakan sarjana telah membesarkan ruang litup definisi konsep penglibatan ini kepada aktiviti-aktiviti yang menjangkaui proses pilihanraya (Huntington dan Nelson, 1976; Scheufele, 2002) seperti menjadi ahli parti politik atau menyumbang dana kepada parti politik dan sebagainya. Scheufele (2002) merujuk konsep tersebut kepada satu aktiviti atau tindakan yang secara langsung atau tidak langsung memberi kesan kepada kerajaan. Menurut Kaase dan Marsh dalam Deth (2000) penglibatan politik adalah satu "aktiviti yang dilakukan secara sukarela oleh rakyat yang mempengaruhi politik secara langsung atau tidak langsung pada pelbagai tahap sistem politik". Wan Asna Wan Mohd Nor, Salfarina Abdul Gapor, Mohamad Zaini Abu Bakar dan Zainon Harun (2011) juga merujuk kepada konteks aktiviti yang lebih luas bukan sekadar sebagai pengundi malah penglibatan dalam parti politik, menghadiri ceramah politik dan menghubungi ADUN kawasan sekiranya ada keperluan dan menyumbang dana kepada parti politik.

Pemahaman tentang konsep ini terus berkembang dengan melihat beberapa tahap dalam penglibatan. Jelasnya mengikut pandangan sarjana seperti Conway (1991), penglibatan politik berlaku pada tahap atau hirarki yang tertentu. Sarjana yang sama misalnya meletakkannya kepada dua tahap penglibatan iaitu penglibatan lazim seperti aktiviti pengundian, mendaftar sebagai pengundi politik dan sebagainya dan penglibatan tidak lazim seperti aktiviti protes atau demonstrasi secara keras atau sebaliknya (Conway, 1991). Begitu juga, Huntington dan Nelson (1976:3) yang mendefinasikan konsep ini sebagai aktiviti-aktiviti oleh warganegara yang dilakukan bagi mempengaruhi keputusan kerajaan yang berlaku sama ada pada tahap individu atau kolektif, secara tersusun atau spontan, sah atau tidak sah, aman atau keras.

Konsep hirarki atau piramid dalam penglibatan politik sebenarnya telah diperkenalkan oleh Milbrath (1965) seperti yang dipetik dari Ruedin (2007) yang telah membahagikan penglibatan politik kepada tiga tahap. Tahap yang asas adalah tahap penonton (yang merujuk kepada aktiviti seperti mengundi dan berbincang tentang politik). Tahap kedua adalah tahap perubah (yang merujuk kepada aktiviti seperti menghadiri ceramah politik, menderma kepada parti politik dan menghubungi pemimpin parti politik), manakala tahap yang tertinggi adalah tahap pejuang yang melibatkan jenis aktiviti advokasi yang lebih serius seperti memegang jawatan dalam parti, berkempen untuk parti dan terlibat sebagai calon pilihanraya.

Walaupun konsepsalisasi pelbagai tahap atau hirarki ini boleh diterima, tetapi ramai juga para sarjana yang membahaskan tentang kekaburan sempadan perbezaan antara tahap-tahap dalam piramid ini (Richardson, 1993 di dalam Ruedin, 2007; Parry, Moyser dan Day, 1992). Misalnya adakah aktiviti berkempen dianggap lebih tinggi tahapnya berbanding aktiviti menderma kepada parti politik? Bagaimana pula dengan protes jalanan? Adakah tahap ini dianggap lebih tinggi hirarkinya berbanding berkempen secara aman?

Disebabkan kekaburan dalam pentafsiran tahap-tahap atau dimensi-dimensi yang terdapat dalam penglibatan politik, maka sarjana seperti Barnes, Kaase, et. al. (1979) dan Parry et. al. (1992) mencadangkan agar konsepsualisasi satu dimensi digunakan. Inilah pendekatan yang digunakan oleh kebanyakan pengkaji dalam bidang ini seperti Scheufele (2002) dan Wan Asna Wan Mohd Nor, Salfarina Abdul Gapor, Mohamad Zaini Abu Bakar dan Zainon Harun (2011). Kesimpulannya, berdasarkan perbincangan tentang konsep penglibatan politik seperti di atas, dapat disimpulkan bahawa penglibatan politik adalah aktiviti-aktiviti yang dilakukan oleh rakyat bagi mempengaruhi kerajaan dan pemerintahan negara tidak terhad kepada tingkahlaku mengundi sahaja.

Di Malaysia, tahap penglibatan politik rakyat terutama dari segi peratusan yang mendaftar untuk mengundi dan peratusan keluar mengundi semasa pilihanraya umum dijalankan sentiasa menunjukkan peningkatan. Misalnya jumlah pengundi berdaftar yang keluar mengundi pada Pilihanraya Umum (PRU) ke-11 adalah 73.9\% dan terus meningkat kepada $76 \%$ pada PRU ke-12 dan $84.84 \%$ pada PRU ke-13 (www.spr.gov.my). Walau bagaimanapun, di sebalik peningkatan ini, didapati terdapat lebih dari empat juta rakyat Malaysia yang layak mendaftar pada tahun 2017 masih belum mendaftar (www.astroawani.com).

Dari segi peratusan yang keluar mengundi semasa pilihanraya diadakan, Malaysia masih lagi agak terkebelakang berbanding Indonesia dan Singapura. Menurut data yang dikeluarkan oleh International Idea Institute for Democracy and Electoral Assistance peratusan yang keluar mengundi di Malaysia pada Pilihanraya Umum 2008 dan 2013 adalah seramai 75.99\% dan 80\%. Jika dibandingkan dengan negara seperti Singapura iaitu sebanyak $93.6 \%$ para pengundi keluar untuk mengundi pada tahun 2015 (www.straitstimes.com/politics/ge2015-voter-turnout-at-9356-per-cent-improves-slightly-from-2011-record-low), masih ada ruang yang boleh diperbaiki di Malaysia, walau peratusan yang keluar mengundi di Malaysia menunjukkan peningkatan dari tahun ke tahun.

Kesedaran dalam penglibatan politik tidak seharusnya dilihat dalam konteks aktiviti pengundian semata-mata. Kesedaran dalam penglibatan politik boleh juga dinilai dalam keberanian membuat keputusan pemilihan. Misalnya dalam PRU ke-12, tsunami politik Malaysia yang didorong oleh peristiwa pemecatan Dato' Seri Anwar Ibrahim, Timbalan Perdana Menteri Malaysia pada tahun 1998, telah menyaksikan perubahan suara rakyat yang menyebabkan kerajaan Barisan Nasional (BN) gagal memperolehi majoriti $2 / 3$ dalam pilihanraya tersebut yang jelasnya menunjukkan minat dan kesedaran masyarakat khususnya golongan muda yang mula melihat betapa suara mereka mampu mencorak perubahan dalam kepimpinan negara. Gelombang suara rakyat yang menuntut perubahan turut dipengaruhi oleh perkembangan media sosial seperti Facebook dan Twitter yang membolehkan interaksi dan perkongsian bahan-bahan kempen politik dengan lebih cepat dan mudah sebagaimana yang dilihat dalam Pilihanraya Umum ke-13 pada 2013 (Junaidi Awang Besar, 2017)

Senario perubahan dari segi penglibatan politik jelasnya didorong oleh pelbagai faktor. Adakah faktor pendedahan kepada media cetak dan media elektronik mampu meningkatkan penglibatan masyarakat dalam politik? Bagaimana pula dengan Internet? Adakah ini disebabkan minat yang semakin tinggi terhadap politik? Adakah individu yang terdedah kepada isu-isu politik di media massa akan lebih terlibat dalam sistem politik negara? Mungkin juga ini didorong oleh faktor umur? Justeru itu kajian ini, yang melihat faktor-faktor yang mempengaruhi penglibatan rakyat dalam sistem politik Malaysia amnya dan di Pulau Pinang khususnya. Kajian ini dianggap penting dan bertepatan dengan senario sosio-politik tempatan yang sentiasa bergolak terutamanya dalam era pasca tsunami politik 2013. 


\subsection{RUJUKAN SARJANA}

Tegaknya amalan demokrasi di sesebuah negara bergantung kepada tahap penglibatan politik warga negaranya. Kajian-kajian lepas terutama yang dijalankan di Barat kerap memperkatakan peranan faktor-faktor dalaman yang mempengaruhi penglibatan politik seperti faktor minat (White, 2003), sikap (Dermody, Hanmer dan Scullion, 2008) dan pengetahuan (Michael dan Carpini, 1999).

Seperti di Barat dan negara-negara lain, terdapat banyak juga kajian tempatan yang dilakukan tentang penglibatan politik rakyat negara ini (Durrishah, Hamidah, Hussein, Ishak dan Norashikin, 2004; Wan Rohila, 2008; Junaidi, 2012) . Tetapi kebanyakan kajian dilihat agak bias dari segi masa dan terhad dari segi skop. Dikatakan bias dari segi masa kerana lebih cenderung dijalankan sewaktu kempen pilihanraya dijalankan (lihat Junaidi, 2012; Willnat, Wong, Tamam \& Aw, 2013; Fatimah \& Ali, 2015; Samsudin, 2010) atau sebaik sahaja selepas pilihanraya diadakan (lihat Wan Rohila, 2008), justeru cenderung memberikan keputusan yang mungkin melampaui dari kebiasaannya.

Kebanyakan kajian lain pula agak kecil skopnya seperti tertumpu kepada gelagat dan corak pengundian sama ada menyokong atau tidak menyokong parti-parti tertentu (Junaidi, 2012) dan terhad dengan melihat cuma kepada beberapa faktor seperti faktor demografi (Wan Asna, Salfarina, Mohamad Zaini dan Zainon (2011), sikap, pengetahuan dan kesedaran (Durrishah, Hamidah, Hussein, Ishak dan Norashikin, 2004), kemampuan kendiri (Merdeka Center for Opinion Research, 2007), reformasi politik (Zawiyah, Mohammad Agus \& Izham, 2015) dan penglibatan wanita dalam politik (Fatimi, Zulkanain, Arbaiyyah \& Mohd Roslan, 2016). Kajian terbaru oleh Salman, Samsudin dan Yusof (2017) juga agak terhad dengan melihat tentang tahap penglibatan belia dalam politik dan kemasyarakatan tanpa cuba mendalami tentang faktor yang mempengaruhinya. Pengkaji mendapati tidak banyak kajian yang dilakukan di Malaysia yang melihat secara menyeluruh tentang faktor dalaman, luaran dan demografi yang mempengaruhi penglibatan politik rakyat kecuali kajian yang dilakukan oleh Wan Rohila (2008) tetapi terhad di kawasan DUN Kuala Berang.

Terdapat beberapa faktor-faktor dalaman seperti minat, sikap dan pengetahuan yang dilihat mempengaruhi tahap penyertaan masyarakat dalam sistem politik negara. Miller dan Rahn (2002), mendefinisikan minat politik sebagai "mahu menyertai" yang mana seseorang itu boleh menunjukkan dengan jelas minat dalam politik dan rasa tidak minat dalam mengambil bahagian dalam politik. Manakala Shani (2008) mendefinisikan minat sebagai motivasi seseorang individu untuk terlibat dalam politik yang mana mengandungi dua dimensi iaitu motivasi untuk belajar mengenai politik dan motivasi untuk terlibat dalam politik. Berdasarkan dua dimensi ini, minat dapat dinilai melalui kecenderungan individu untuk mengambiltahu tentang berita politik semasa berbanding berita-berita lain atau cenderung untuk terlibat dalam politik seperti dengan berkempen untuk parti politik yang disokong.

Menurut Patterson (dalam Lammie, 2009), kajian terbaru menyatakan bahawa golongan belia pada hari ini kurang berminat dan terlibat dalam politik. Menurut U.S. Census Bureau, golongan belia yang terlibat dalam lapan pilihan raya dari tahun 1972 hingga 2000 telah berkurangan dari 50, 42, 40, 41, 34, 32, sehingga 31 peratus. Kajian yang telah dijalankan oleh White (2003) mendapati golongan belia boleh diklasifikasikan kepada lima kumpulan yang berbeza yang mana setiap satunya menunjukkan minat berlainan. Dua daripada lima kumpulan berkenaan menunjukkan tidak berminat dalam politik, yang mana setiap satunya daripada kumpulan berkenaan menyatakan tidak suka akan politik dan mempunyai persepsi yang sama iaitu politik adalah sesuatu yang membosankan. Hal ini menunjukkan penglibatan seseorang dalam politik bergantung kepada minat mereka dalam politik, jika seseorang itu kurang berminat dalam politik, maka kadar penglibatan mereka dalam poltik adalah lebih rendah.

Selain faktor minat terhadap politik, sikap juga adalah faktor yang menyumbang kepada faktor penglibatan politik. Hamdan Adnan (1995) menyatakan sikap adalah kecenderungan untuk bertindak balas mengikut sesuatu cara yang tertentu terhadap sesuatu atau suasana tertentu, manakala menurut Rosenberg dan HovIand (1960) pula sikap mempunyai tiga komponen iaitu kognitif, afektif dan konatif. Mengabung jalin kedua definisi di atas maka sikap dapat disimpulkan sebagai kecenderungan untuk bertindakbalas sama ada secara kognitif, afektif and konatif terhadap politik dan isu-isu yang berkaitan dengannya, misalnya percaya bahawa sistem politik Malaysia adalah telus (kognitif), benci kepada amalan politik yang kotor (afektif) dan cenderung mengundi semasa pilihanraya (konatif).

Kajian yang telah dilakukan oleh Dermody, Hanmer dan Scullion (2008) di Britain, menunjukkan bahawa golongan belia adalah golongan yang paling kurang terbabit dalam pilihan raya walaupun telah layak mengundi, malahan sikap tidak mengundi ini berterusan sepanjang hidup mereka. Oleh itu bagi kumpulan umur ini, sikap tidak mengundi telah menjadi norma atau satu kebiasaan.

Beberapa kajian tempatan telah dijalankan mengenai sikap masyarakat terhadap politik, antaranya adalah kajian oleh Durrishah, Hamidah, Hussein, Ishak dan Norashikin (2004) dalam kalangan 209 responden di Johor menunjukkan faktor sikap tidak kisah dan tidak ambil peduli merupakan antara faktor yang menyebabkan golongan yang sepatutnya mendaftar sebagai pengundi tidak melakukan tanggungjawab tersebut. Dapatan yang hampir sama dapat dilihat dalam satu kajian nasional yang dijalankan oleh Suruhanjaya Pilihanraya Malaysia dengan kerjasama Universiti Teknologi Malaysia dan menunjukkan bahawa sikap tidak ambil peduli dan kesibukan bekerja adalah antara faktor terpenting selepas faktor kelemahan dari segi infrastruktur (terpaksa beratur dan menunggu lama) (http://www.spr.gov.my).

Pengetahuan umum tentang isu-isu politik juga dilihat mempengaruhi penglibatan dalam politik, walaupun mungkin tidak menjadi faktor yang siknifikan kerana kajian yang dijalankan oleh Suruhanjaya Pilihanraya Malaysia dengan kerjasama Universiti Teknologi Malaysia menunjukkan kebanyakan golongan yang berpotensi mendaftar sebagai pengundi, tetapi tidak melakukannya walaupun mempunyai pengetahuan dan kesedaran yang tinggi tentang kelayakan sebagai pengundi, hak mendaftar, dan tanggungjawab mengundi. Walau bagaimanapun Michael dan Carpini (1999), menekankan bahawa semasa kempen pilihan raya, pengetahuan calon dan pendirian mereka terhadap sesuatu isu memudahkan perjalanan pengundian, selain itu pengetahuan yang tepat dan meluas membantu masyarakat untuk membuat keputusan yang bersesuaian dengan sikap mereka terhadap politik, kepercayaan dan minat.

Pengetahuan mengikut Mohamad Sahari Nordin (2001) adalah proses memilih, mempersoal, membina dan mencantum informasi. Oleh sebab itu, orang yang berpengetahuan biasanya mempunyai keupayaan untuk menerangkan sesuatu yang diketahuinya (Pojman 1999). Berkaitan dengan perkara di atas, pengetahuan tentang politik boleh dinilai dari keupayaan individu menyatakan dan menerangkan informasi, isu-isu atau individu yang penting dalam politik seperti nama Ahli Dewan Undangan Negeri atau prinsip atau slogan pentadbiran kerajaan.

Faktor demografi umur adalah antara ciri-ciri demografi yang penting dalam mendorong penglibatan dan penyertaan rakyat dalam politik. Banyak kajian terutamanya di Barat menunjukkan bahawa golongan belia kurang melibatkan diri dalam politik negara. Menurut White (2003), penglibatan golongan belia dalam politik nasional dan tempatan menjadi isu yang membimbangkan di UK dan beberapa 
tempat lain bermula awal 1990an. Walau bagaimanapun sejak akhir-akhir ini, keengganan rakyat untuk keluar mengundi terutamanya bagi golongan belia telah menjadi isu penting bagi sistem demokratik di Britain. Hal ini telah menimbulkan kebimbangan kerana peningkatan golongan ini yang tidak keluar mengundi pada pilihan raya (Phelps, 2005). Hal ini terbukti apabila hanya 39 peratus mereka yang berumur 18 hingga 24 tahun dan layak mengundi keluar untuk mengundi pada tahun 2001 bagi pilihan raya umum di Britain, dan pada tahun 2005 , peratusan menurun kepada 37 peratus (Henn, Weinstein dan Hodgkin, 2007). Kajian terbaru oleh Ahmad, Syed dan Sani (2017) juga menunjukkan golongan belia di Jepun menunjukkan minat yang yang rendah terhadap politik dalam kalangan belia di Jepun. Sebaliknya mereka lebih menunjukkan minat yang lebih tinggi terhadap isu-isu kemasyarakatan, sosial dan alam sekitar. Dapatan kajian oleh Salman, Samsudin dan Yusof (2017) juga menunjukkan pola yang hampir sama di Malaysia di mana belia Malaysia kini didapati menunjukkan tahap penglibatan yang rendah dalam politik. Belia Malaysia didapati kurang melibatkan diri dalam aktiviti yang dianjurkan oleh parti politik atau berjumpa dengan ahli parlimen/ahli dewan undangan negeri yang dilantik bagi membincangkan isu-isu atau menyuarakan pendapat. Tetapi belia Malaysia didapati lebih cenderung melibatkan diri dalam aktiviti kemasyarakatan seperti melibatkan diri dalam aktiviti kitar semula, program kebajikan masyarakat dan aktiviti kesukarelawan.

Menurut Skipworth (2009), bagi golongan belia yang baru memasuki dunia politik, mereka kekurangan pengalaman dan akhirnya kesedaran politik mereka menjadi kurang berbanding golongan yang lebih tua. Hal ini kerana, pengalaman seseorang mempunyai kaitan dengan umur. Oleh yang demikian, peluang dan pengalaman seseorang memberikan perbezaan terhadap penglibatan politik, yang mana mempengaruhi tahap kesedaran politik individu tersebut.

Golongan muda mempunyai alasan dan faktor mengapa mereka sukar terlibat dalam politik. Kajian yang dilakukan oleh White, Bruce, Ritchie (2000) mendapati, politik adalah perkara yang membosankan. Ramai golongan belia menyatakan bahawa mereka lebih tertarik untuk melakukan aktiviti lain dan hanya memberikan sedikit masa untuk perihal politik. Malahan, golongan ini turut menanam konsep bahawa politik hanya untuk golongan tua. Selain itu, golongan belia juga mendapati bahawa politik adalah sesuatu perkara yang kompleks. Golongan muda ini menyatakan, mereka mengalami kesukaran untuk memahami bahasa yang digunakan dalam politik, sebagai contoh dalam politik mereka menggunakan perkataan yang kompleks dan sukar difahami. Hal ini terjadi berikutan golongan ini kurang terdedah kepada maklumat mengenai politik dan akhirnya menyebabkan mereka memilih untuk tidak mengambil tahu mengenai maklumat politik (White, Bruce dan Ritchie, 2000).

Dalam konteks negara Malaysia pada hari ini, faktor umur menjadi sesuatu yang cukup penting dalam menilai penglibatan politik hari ini. Secara umumnya belia di Malaysia masih lagi dilihat kurang aktif dalam aktiviti politik kerana apa yang dipentingkan mereka adalah peluang pekerjaan, keselamatan dan kualiti hidup yang lebih baik. Disebabkan minat yang kurang terhadap politik negara, dikatakan $62 \%$ dari mereka atau 7 juta masih lagi bersikap belum memihak atau "atas pagar" kepada mana-mana parti (www.thestar.com.my/news/).

Walau bagaimanapun kemelut politik negara sejak tahun 1998 yang diikuti dengan "tsunami politik" negara pada tahun 2008 telah menyebabkan timbul minat golongan belia negara terhadap politik. Pendaftaran pengundi muda telah meningkat naik dengan mendadak hasil kesedaran yang tinggi tentang kepentingan mereka dalam melakukan perubahan dalam sistem politik negara. Hasil kajian pada tahun 2010 oleh Samsudin A Rahim dalam kalangan 8823 belia yang berumur 21-40 tahun menunjukkan kesedaran sosial dan politik yang membanggakan dalam kebanyakan responden. Mereka menunjukkan keperihatinan tentang isu-isu yang dibangkitkan semasa pilihanraya ke-12 seperti kenaikan harga barang, keselamatan, kesamarataan kaum dan rasuah. Walau bagaimanapun, mungkinkah timbul bias keran

Oleh itu boleh disimpulkan bahawa, umur memainkan peranan yang penting dalam mempengaruhi penglibatan seseorang dalam politik. Sekiranya dulu, golongan muda tidak mengambil peduli tentang isu-isu politik negara, tetapi pada hari ini mereka mula merasakan kepentingan suara mereka turut didengar oleh parti yang memerintah.

Selain dari faktor dalaman, faktor luaran turut mendorong penglibatan seseorang individu dalam sistem politik sesebuah negara. Antara faktor luaran yang pernah dikaji adalah seperti pengaruh media massa (Syed Arabi Idid dan Shafizan Mohamed, 2006; Chandra Muzaffar dan Syamsuddin Haris (1989), profil calon bertanding (Mohd Faisal, Neilson dan Ahi, 2002); komunikasi interpersonal (Scheufele, 2002), Kajian terbaru yang dijalankan oleh Suruhanjaya Pilihanraya Malaysia (2010) turut menunjukkan faktor kekangan infrastruktur fizikal (seperti terpaksa beratur and menunggu lama di kaunter) amat mempengaruhi golongan muda untuk tidak mendaftar sebagai pengundi.

Pengaruh daripada sumber media seperti surat khabar, televisyen, radio dan Internet malahan melalui perbincangan interpersonal mengenai politik dalam kalangan rakyat itu sendiri dilihat mempengaruhi tahap penglibatan politik rakyat. Hasmah Zainuddin dan Yuana King (2006), mendapati bahawa penggunaan media massa terutama akhbar berperanan mewujudkan kesedaran sosial melalui berita yang dilaporkan. Pembacaan akhbar memberikan kesan terhadap tingkah laku khalayak termasuklah seperti langkah berhati-hati terhadap persekitaran, manakala media elektronik seperti televisyen pula berperanan untuk mengutarakan berita yang benar dan tepat termasuk untuk mendapatkan maklumat tentang politik negara. Menurut Azmah Abdul Manaf (2001), media massa bukan sahaja berfungsi sebagai satu alat penyampai maklumat sahaja, tetapi ia penting dalam proses mencetus dan seterusnya memupuk kesedaran sosial dan politik dalam kalangan para pembaca. Justeru itu individu yang banyak terdedah kepada media massa (samaada media aliran perdana atau media alternatif) dan kandungan berita-berita hal-ehwal semasa termasuk politik akan lebih memahami isu politik dengan lebih jelas, sekaligus akan lebih terdorong melibatkan diri dalam sistem politik negara sama ada dengan mendaftar sebagai pengundi atau menjadi pengundi.

Menurut Lemert (1992), media memainkan peranan yang sangat penting dalam menyediakan apa yang dipanggil sebagai 'mobilising information'. Mobilising information adalah kandungan yang lebih mendalam mengenai maklumat mengenai sistem politik yang membolehkan masyarakat memahami masalah yang berkait dengan komuniti dan menarik penyertaan dalam pelbagai aktiviti masyarakat. Walau bagaimanapun, Schudson dalam Eveland dan Scheufele (2000) mengemukakan alasan, realitinya kini, ia menyimpang daripada apa yang sepatutnya. Mobilising information semakin hari semakin kurang. Beliau menegaskan dalam surat khabar pada hari ini, walaupun terdapatnya mobilising information, ia ditempatkan dalam bahagian yang tidak penting.

Kesan media yang lebih berkuasa ditunjukkan dalam kajian yang dilakukan oleh Syed Arabi Idid dan Shafizan Mohamed (2006), yang merumuskan bahawa media massa mempunyai kesan 'pengaktifan', 'memperkukuh' dan 'penukaran' terhadap pengundi semasa kempen pilihan raya. Hasil kajian yang telah dijalankan pada pilihan raya 2004 mendapati, media (televisyen dan surat khabar) mempunyai kesan yang berkesan terhadap penyokong BN, manakala penyokong PAS, DAP, KeAdilan dan penyokong parti yang lain hanya mendapat kesan yang minimum. Hal ini kerana rakyat Malaysia percaya bahawa media mempunyai hubungan dan memberikan personaliti kepada parti pemerintah, oleh itu mereka berjaya mempengaruhi penyokong $\mathrm{BN}$ dan tidak bagi penyokong parti lain. 
Selain dari penggunaan media massa yang mampu mencorak keputusan pengundian, penggunaan komunikasi interpersonal dilihat saling berkait dalam meningkatkan tahap penglibatan rakyat dalam politik. Menurut Robinson dan Levy (1986), perbincangan interpersonal mengenai sesuatu berita politik adalah antara faktor penting dalam memahami sesuatu berita jika dibandingkan dengan pendedahan maklumat politik dari media. Para pengkaji juga menyatakan bahawa perbincangan interpersonal mengenai politik mempunyai kaitan yang penting dengan kepelbagaian penglibatan politik dan pemahaman terhadap isu tersebut.

Menurut Scheufele (2002), wujud perhubungan antara perbincangan interpersonal mengenai politik dan jenis media terhadap kesan penglibatan politik. McLeod, Scheufele, dan Moy (1999), menyatakan bahawa kepelbagaian jenis komunikasi dan maklumat yang diterima akan menghasilkan kelainan dalam penglibatan politik. Seterusnya menurut Eveland dan Scheufele (2000), pemahaman masyarakat terhadap politik bergantung pada kesan interaktif media massa dan perbincangan interpersonal mengenai politik.

Scheufele (2001) telah melabelkan interaksi antara media massa dan perbincangan interpersonal mengenai politik sebagai model Differential Gains. Konsep ini dikonseptualisasi untuk mengetahui sama ada perbincangan interpersonal mengenai politik akan menjadi penghubung kepada pendedahan berita dari media massa kepada audien dan seterusnya meningkatkan pemahaman mengenai isu politik dan sosial.

Model ini mengandaikan bahawa perbincangan interpersonal mengenai politik memainkan peranan penting dalam memahami berita politik dan mesej dari media massa. Interaksi pendedahan berita dari media massa dan perbincangan interpersonal mengenai politik memberi kesan terhadap penglibatan politik (Scheufele, 2002). Menurutnya lagi, kesan penglibatan politik dari seseorang individu akan lebih tinggi jika individu berkenaan terdedah kepada berita politik yang relevan melalui media massa dan kemudian dalam masa yang sama membuat perbincangan interpersonal mengenai politik tersebut dengan orang lain. Namun penglibatan politik individu tersebut akan kurang jika mereka hanya terdedah kepada salah satu medium sahaja iaitu sama ada melalui media massa atau hanya melalui perbincangan interpersonal mengenai politik.

Menurut Eveland dan Scheufele (2000), Model Differential Gains melihat bahawa kesan penglibatan politik daripada pendedahan berita dari media massa bergantung kepada pengaruh perbincangan interpersonal mengenai politik. Dalam kata lain, perbincangan interpersonal tentang politik atau disebut sebagai "political talk" memainkan peranan perantara antara pendedahan berita politik dari media massa dan penglibatan politik. Manakala Scheufele (2002) menyatakan individu yang lebih banyak bercakap atau berbincang mengenai isu politik selepas terdedah dengan berita politik dari media massa mempunyai tahap pengetahuan yang lebih tinggi mengenai politik berbanding dengan mereka yang kurang melakukannya. Model ini mengandaikan bahawa media massa tidak selalu mempunyai pengaruh secara langsung terhadap pengetahuan politik masyarakat dan penglibatan mereka dalam politik, namun kesan pendedahan berita politik dari media massa terhadap kesan penglibatan politik bergantung pada perbincangan interpersonal mengenai politik dengan orang lain. Perbincangan interpersonal tentang politik ini dapat dinilai dari tahap kekerapan individu berdiskusi dan bertukar-tukar pandangan tentang isu-isu berkaitan politik bersama rakan-rakan, keluarga dan masyarakat setempat. Teori ini secara khususnya melibat kesan beberapa angkubah media seperti pendedahan kepada media cetak, pendedahan kepada televisyen dan pendedahan kepada Internet terhadap penglibatan politik melalui pengantaraan perbincangan politik. Kajian-kajian terbaru yang mengaplikasikan model ini turut memasukkan angkubah tambahan seperti tahap akses kepada Internet, tahap pendedahan kepada kempen politik dan tahap kekuatan ideologi politik (Nisbet \& Scheufele, 2004). Kajian oleh Lin (2016) turut menilai kesan perbincangan interpersonal dalam Facebook terhadap penglibatan politik didapati lebih tinggi dalam kalangan pengundi muda di Taiwan yang pertama kali mengundi dalam pilihanraya berbanding pengundi senior. Dalam kajian ini, pengundi muda yang aktif menggunakan Facebook bagi berkongsi maklumat tentang politik akan cenderung untuk mengundi dalam pilihanraya. Kajian terbaru oleh Reichert dan Print (2017) turut menguji model ini terhadap beberapa pemboleh ubah bersandar yang lain termasuk penglibatan kemasyarakatan bukan sekadar penglibatan politik. Hasil kajian menunjukkan peranan perantara yang siknifikan bagi perbincangan interpersonal bagi meningkatkan tahap penglibatan kemasyarakatan. Kajian Reichert dan Print (2017) jelasnya telah memanjangkan ruang litup teori ini kepada penglibatan kemasyarakatan, bukan hanya penglibatan politik sekaligus membuktikan kepentingan peranan perantara pembincangan interpersonal dalam menyokong maklumat yang disampaikan melalui media arus perdana.

Berdasarkan perbincangan di atas, jelaslah bahawa terdapat beberapa faktor yang mempengaruhi penglibatan politik seseorang individu. Justeru itu, kajian ini bertujuan untuk mengetahui sama ada faktor dalaman (minat terhadap politik, sikap terhadap politik, pengetahuan umum dan umur) dan faktor luaran (surat khabar, Internet, televisyen, radio, perbincangan interpersonal mengenai politik) mempengaruhi penglibatan dalam politik.

\section{Latar Belakang Sosio-Politik Malaysia}

Malaysia adalah sebuah negara yang mempunyai komposisi masyarakat yang berbilang kaum, yang majoritinya terdiri dari kaum Melayu dan Bumiputera $(60.6 \%)$, kaum Cina (22.8\%), kaum India $(6.8 \%)$ dan lain-lain kaum $(9.8 \%)$. Islam adalah agama rasmi negara, tetapi agama-agama lain seperti Buddha, Hindu dan Kristian bebas dianuti dan diamalkan. Dengan populasi terkini sekitar 32 juta pada tahun 2017, majoriti populasi (63\%) adalah berumur antara 15-64 tahun (www.dosm.gov.my). Median umur bagi populasi di Malaysia adalah 20.6, sekaligus menggambarkan purata umur populasi yang masih muda. Nisbah lelaki kepada perempuan adalah hampir sama. Perempuan didapati mempunyai jangka hayat yang lebih tinggi iaitu 77.2 tahun berbanding lelaki pada 72.3 tahun.

Sejak mencapai kemerdekaan dari penjajahan Britain pada 1957, Malaysia terus mengamalkan sistem Demokrasi Berparlimen di bawah pentadbiran Raja Berpelembagaan yang diketuai oleh Seri Paduka Baginda Yang Di-Pertuan Agong. Seperti negara-negara demokrasi yang lain, Malaysia mengamalkan pembahagian kuasa kepada tiga bahagian dalam pemerintahan iaitu Perundangan, Kehakiman dan Eksekutif. Mandat rakyat terhadap kerajaan yang dipilih diperolehi melalui pilihanraya yang diadakan setiap lima tahun sekali. Wakil-wakil rakyat yang dipilih melalui pilihanraya umum akan dilantik sebagai ahli dalam dalam Dewan Rakyat (222 ahli) dan Dewan Undangan Negeri yang jumlahnya berbeza mengikut negeri. Dalam sistem Demokrasi Berparlimen, peranan wakil rakyat dianggap sangat penting dalam menyampaikan masalah, harapan dan suara hati rakyat kepada kerajaan yang dipilih.

Pilihanraya diadakan lima tahun sekali dengan yang terakhir iaitu Pilihanraya ke-13 dijalankan pada tahun 2013. Setiap rakyat Malaysia yang berumur 21 tahun dan telah mendaftar dengan Suruhanjaya Pilihanraya Malaysia layak mengundi bagi memilih wakil rakyat mereka. Parti yang mempunyai jumlah wakil rakyat yang paling banyak akan membentuk kerajaan persekutuan. Sejak merdeka 
parti Barisan Nasional terus menerajui pemerintahan persekutuan. Pada peringkat negeri, parti yang sama masih mengekalkan pemerintahan di kesemua negeri kecuali Kelantan, Selangor dan Pulau Pinang.

Dari segi pemilikan media, tidak seperti jirannya yang terdekat iaitu Indonesia, media di Malaysia masih lagi dilihat bertatih dalam langkah mencapai kebebasan media. Operasi media sentiasa dipantau oleh kerajaan terutamanya melalui sekatan undang-undang (Hilley, 2001) seperti Ordinan Fitnah 1957, Akta Mesin Cetak 1948 (dipinda pada tahun 1974), Akta Hasutan 1948 (dipinda pada tahun 1972 ), Akta Kawalan Kemasukan Bahan-Bahan Bercetak 1958 (dipinda pada tahun 1972) dan Akta Rahsia Rasmi 1972 yang dikatakan perlu bagi memastikan kestabilan negara terutama apabila melibatkan isu-isu sensitif yang melibatkan sensitiviti kaum dan agama.

Walaupun media massa di Malaysia terbahagi kepada dua kategori, media yang dimiliki oleh kerajaan dan media swasta, namun jika ditinjau dengan teliti, bukan sahaja media kerajaan malah media swasta secara tidak langsung juga dimiliki oleh parti-parti politik pemerintah atau pemiliknya mempunyai kaitan dengan pemimpin parti politik pemerintah (Hilley, 2001). Suara-suara lantang yang mendesak pihak pemerintah agar memberi kebebasan yang lebih luas kepada media terus kedengaran, terutama dengan beberapa kes penolakan permohonan permit penerbitan Suara Keadilan dan FZ Daily oleh Kementerian Dalam Negeri pada 2014 (www.thestar.com.my). Disebalik semua itu, Indeks Kebebasan Media Malaysia dilihat meningkat naik ke tangga 144 pada tahun 2017 berbanding 146 pada 2016, iaitu 7 tangga lebih baik dari Singapura yang berada pada tahap 151 (https://rsf.org/en/ranking/2017?\#).

Suara-suara keras yang melaungkan gesaan terhadap amalan kebebasan akhbar yang lebih luas terus jelas kedengaran, walaupun hakikatnya konsep kebebasan akhbar yang mutlak tidak akan pernah tercapai. Ruhanie Ahmad (2009) dalam huraiannya tentang hal ini menyatakan bahawa konsep kebebasan akhbar termaktub dalam Deklarasi Hak Asasi Manusia Sejagat yang diluluskan oleh PBB pada 10 Disember 1948 yang menyatakan, setiap individu mempunyai hak kepada kebebasan bersuara dan pendapat. Hak ini termasuklah kebebasan memperoleh, menerima dan menyebarkan maklumat serta idea menerusi sebarang media tanpa mengira sempadan.

Walau bagaimanapun, Artikel 29(3) deklarasi berkenaan menegaskan, seluruh hak dan kebebasan tidak boleh bercanggah dengan seluruh matlamat dan prinsip utama PBB iaitu pengamalan toleransi dan kehidupan bersama secara aman; bersatu memelihara keamanan dan keselamatan antarabangsa; menghapuskan seluruh ancaman kepada keamanan; pemansuhan tindakan-tindakan ganas; dan bertindak selaras dengan undang-undang antarabangsa untuk meleraikan persengketaan atau lain-lain tindakan yang menjejaskan keamanan. Menurut beliau lagi, ini jelas membuktikan bahawa kebebasan akhbar yang dijamin oleh Deklarasi Hak Asasi Manusia Sejagat adalah kebebasan yang terhad, bersyarat, mempunyai batas dan mempunyai sekatan.

\section{Senario Politik Di Pulau Pinang}

Kemelut politik di Malaysia pada 1998 yang menyaksikan pemecatan Dato' Seri Anwar Ibrahim, Timbalan Perdana Menteri Malaysia pada ketika itu, telah memberi kesan terhadap kesedaran, minat, kecenderungan dan tahap penglibatan politik bukan sahaja di Pulau Pinang, malah di seluruh Malaysia. Gelombang kebangkitan rakyat ini telah membawa kepada tsunami politik 2008 yang menyaksikan BN memenangi hanya 51.4\% dari keseluruhan 7942803 undi sekaligus mengubah seluruh lanskap pemerintahan termasuk di negeri Pulau Pinang yang selama ini diterajui oleh Barisan Nasional melalui parti-parti komponennya iaitu Gerakan dan UMNO. Selepas pilihanraya ke-12 pada 2008, pemerintahan negeri Pulau Pinang telah diambilalih oleh Pakatan Rakyat yang telah membentuk kerajaan campuran setelah parti DAP memenangi 19 Dewan Undangan Negeri (DUN), manakala PKR memenangi 9 DUN dan PAS memenangi 1 DUN dari keseluruhannya 40 kerusi DUN di negeri tersebut. Kemenangan Pakatan Rakyat berterusan semasa Pilihanraya Umur ke-13 dengan Pakatan Rakyat menguasai 2/3 dalam Dewan Undangan Negeri Pulau Pinang

Tahap penglibatan politik sekiranya dinilai dari segi peratusan yang keluar mengundi di Pulau Pinang dalam PRU ke-12 adalah $77.1 \%$ dan meningkat kepada lebih $86.8 \%$ dalam PRU ke-13. Peratusan ini adalah antara yang tertinggi berbanding pengundi di negeri-negeri lain, malah melebihi peratusan keseluruhan iaitu $84.5 \%$ (www.nst.com.my).

Jelasnya, tahap penglibatan politik yang tinggi jika dinilai dari peratusan yang keluar mengundi di Pulau Pinang, mendorong kepada berlakunya Tsunami politik 2008 dan Tsunami politik kaum Cina 2013 yang menyaksikan negeri Pulau Pinang terus kekal ke tangan Pakatan Rakyat. Ini jelas menunjukkan gelombang perubahan politik rakyat negeri tersebut terutama kaum Melayu yang dilihat berani membuat perubahan dalam pemilihan teraju kepimpinan dan pemerintahan negeri tersebut dalam PRU ke-12 dan penolakan secara total kaum Cina terhadap Barisan Nasional dalam PRU ke-13. Komposisi kaum yang agak setara di Pulau Pinang menjadikan situasi politik di Pulau Pinang sering bergolak dan dibelenggu sensitiviti agama dan kaum.

\subsection{KAEDAH KAJIAN}

\section{Sampel Kajian}

Kajian ini memfokuskan kepada pengundi-pengundi di Pulau Pinang kerana komposisi etniknya yang agak seimbang iaitu Bumiputera seramai 636,200, Cina seramai 671,300 dan India seramai (156, 800) pada tahun 2015 (http://www.penang.gov.my) membolehkan perbandingan yang lebih tepat dalam konteks masyarakat yang berbilang kaum. Pulau Pinang merupakan satu-satunya negeri selepas Wilayah Persekutuan Kuala Lumpur yang mempunyai jumlah penduduk berketurunan Cina yang melebih 50\% (www.themalaysiainsider.com). Di samping itu, tahap penglibatan politik dalam kalangan rakyat di Pulau Pinang sentiasa menunjukkan peningkatan misalnya pada PRU ke- 11 dari 75.8\% kepada 77. 1\% pada PRU ke-12 membantu penyelidik melihat dengan lebih jelas apakah faktor-faktor seperti minat, pengetahuan dalam politik dan sebagainya yang mendorong perkembangan ini.

Bagi mengurangkan kesan dapatan yang bias, sekiranya dijalankan sewaktu kempen pilihanraya diadakan, kajian ini dijalankan di luar waktu pilihanraya umum. Kajian menggunakan kaedah tinjauan berpandukan kertas soal selidik berstruktur. Sampel yang dipilih bagi kajian ini adalah sebanyak 386 orang dengan menggunakan kaedah pelbagai tahap (multi-stage cluster sampling) yang dipilih daripada daerah-daerah yang ada di negeri Pulau Pinang dan persampelan convenience. Kajian menumpukan kepada dua daerah utama iaitu Daerah Barat Daya dan Daerah Timur Laut yang terletak di bahagian pulau yang melibatkan 19 Dewan Undangan Negeri. Daripada 19 Dewan 
Undangan Negeri ini, empat Dewan Undangan Negeri dipilih secara rawak yang melibatkan kawasan Bayan Lepas, Batu Uban, Tanjung Bunga dan Pulau Tikus. Dari jumlah ini, sampel seterusnya dipilih menggunakan persampelan convenience, di mana penyelidik mensasarkan isi rumah di kawasan Dewan Undangan Negeri tersebut. Kriteria penting dalam pemilihan sampel terdiri daripada mereka yang berumur 21 tahun dan ke atas.

\section{Pengukuran}

Terdapat sepuluh pemboleh ubah yang dikaji dalam kajian ini iaitu faktor demografi umur, minat terhadap politik, sikap terhadap politik, pengetahuan umum tentang politik negara, penggunaan televisyen, penggunaan radio, penggunaan surat khabar, penggunaan Internet, perbincangan interpersonal tentang politik dan penglibatan dalam politik. Bagi faktor demografi umur, pengukuran dilakukan dengan menanyakan umur responden pada tahun kajian dilakukan.

Pembolehubah minat terhadap politik telah diukur menggunakan sembilan kenyataan yang perlu dijawab menggunakan skala Likert lima mata dari "sangat tidak setuju" kepada "sangat setuju". Antara kenyataan yang diberikan adalah "Jika saya mempunyai masa lapang, saya akan lebih mengutamakan berita perihal politik berbanding perkara lain" dan "Saya lebih mengutamakan berita berhubung isu politik berbanding berita-berita lain". Kesemua soalan ini dipetik dari Shani (2008) dan mencatatkan nilai kebolehpercayaan 0.944. Sikap terhadap politik telah diukur menerusi enam kenyataan. Antara kenyataan yang diberikan adalah "Saya suka perubahan politik yang berlaku hari ini" dan "Saya percaya keadilan dalam politik". Responden perlu menjawab kenyataan ini menggunakan skala Likert lima mata dari "sangat tidak setuju" kepada "sangat setuju". Kebanyakan soalan dipetik dan diubahsuai dari Scheufele (2002) dan merekodkan nilai kebolehpercayaan 0.965 .

Bagi pembolehubah pengetahuan umum berkenaan politik negara, sebanyak lapan soalan berbentuk terbuka telah ditanya. Secara amnya soalan tertumpu kepada pengetahuan umum responden mengenai negara dan politik Malaysia. Antara soalan yang ditanya adalah seperti berikut, "Bagi mencapai matlamat KPI dengan lebih berkesan kerajaan telah mengumumkan 6 NKRA (National Key result Area), Sila nyatakan salah satu prinsip NKRA tersebut (contoh: mengurangkan rasuah); dan "Terdapat tiga prinsip pentadbiran Kerajaan Pulau Pinang, atau diringkaskan kepada CAT, sila nyatakan salah satu daripada prinsip tersebut". Responden diberikan markah berdasarkan jawapan betul yang diberikan. Kesemua soalan direkabentuk oleh penyelidik dengan mengambil kira bentuk soalan yang sama yang ditanya oleh Scheufele (2002).

Pengukuran bagi pembolehubah 5-8 iaitu penggunaan televisyen, radio, suratkhabar dan Internet diukur menggunakan skala Likert empat mata dari "tidak pernah", sekali seminggu, 2-3 kali seminggu dan "setiap hari". Responden diminta menyatakan kekerapan mereka menonton televisyen, mendengar radio, membaca surat khabar dan melayari Internet. Mereka juga diminta merekodkan kekerapan mereka menonton, mendengar, membaca dan melayari bahan-bahan berita tentang hal-ehwal semasa (politik, ekonomi, sosial dan lain-lain) di kesemua media tersebut. Kebanyakan soalan dipetik dari Scheufele (2002) dan Rojas dan Puig-i-Abril (2009) dan mencatatkan nilai kebolehpercayaan melebihi nilai minima 0.7 .

Soalan yang dibentuk bagi pembolehubah yang kesembilan iaitu perbincangan interpersonal mengenai politik juga dipetik dari Scheufele (2002). Sebanyak empat kenyataan disediakan yang perlu dijawab menggunakan skala Likert empat mata, iaitu dari "tidak pernah", "sekali seminggu", "2-3 hari seminggu", atau "setiap hari". Bagi pembolehubah ini responden diminta untuk menyatakan kekerapan mereka mengadakan perbincangan interpersonal mengenai isu politik dengan ahli keluarga dan rakan-rakan dalam masa seminggu yang lepas. Antara kenyataan yang digunakan bagi tujuan pengukuran adalah seperti berikut: "Berbincang mengenai isu politik dengan rakan rakan"; "Mendapat maklumat tentang politik melalui perbincangan interpersonal dengan rakan rakan" dan "Berbincang mengenai isu politik dengan keluarga”. Nilai kebolehpercayaan bagi item-item perbincangan politik adalah 0.865 .

Terakhir adalah penglibatan politik yang diukur menggunakan skala Likert lima mata iaitu tidak pernah (1), jarang (2), neutral (3), kerap (4), sangat kerap (5). Tujuh soalan yang digunakan dipetik dari Scheufele (2002) dan Rojas, Puig-i-Abril (2009). Selaras dengan pandangan Richardson (1993) dan Parry et. al. (1992), tiada hirarki atau tahap diletakkan bagi setiap item penglibatan politik. Kesemua sembilan item yang digunakan tidak hanya mengukur kepada aktiviti mengundi sahaja tetapi turut melibatkan aktiviti-aktiviti politik lain dan ini termasuk "Menghadiri kempen politik", "Menghadiri mesyuarat tentang politik", "Membantu mengutip derma untuk parti politik", "Menjadi ahli yang berdaftar dalam parti politik" dan "Memegang jawatan dalam parti politik", "Mengundi dalam pilihanraya", "Mengedarkan bahan-bahan promosi bagi calon/parti", "Menderma duit untuk kempen calon politik" dan "Mempromosi parti kepada rakan-rakan agar menjadi ahli" Nilai kebolehpercayaan bagi item-item ini adalah 0.934.

\subsection{DAPATAN KAJIAN DAN PERBINCANGAN}

Dari segi demografi, majoriti responden yang terlibat dalam kajian ini adalah bangsa Cina 49\%, Melayu 37.83\% diikuti oleh India $13.2 \%$. Peratusan pembahagian jantina hampir seimbang dengan majoriti responden adalah golongan lelaki $51.0 \%$ manakala bilangan responden perempuan adalah $49.0 \%$. Dari segi umur, sebanyak 53.9\% responden berumur dalam kategori $21-30$ tahun, $24.4 \%$ berumur $31-40$, $15.5 \%$ berumur 41-50, 5.4\% berumur 51-60 dan hanya 0.8\% berumur 61-70 tahun. Bagi status pekerjaan, majoriti responden bekerja dalam sektor swasta $52.1 \%$, diikuti dengan sektor awam $15.3 \%$, bekerja sendiri $14.8 \%$, manakala baki sebanyak $17.9 \%$ mewakili responden yang tidak bekerja dan masih belajar. Tahap pencapaian pendidikan yang mencatatkan peratusan yang paling tinggi adalah sekolah menengah $38.9 \%$, diikuti ijazah dan ijazah tinggi 31.1\% diploma 28.0\%, manakala peratusan terendah diwakili oleh sekolah rendah $2.1 \%$.

Jika dilihat dari tahap penglibatan politik, berdasarkan kaum, kaum Melayu di Pulau Pinang didapati menunjukkan tahap penglibatan politik yang paling rendah terutama dari segi menderma untuk parti politik dan berkempen untuk parti politik, berbanding kaum Cina dan kaum India (Melayu: min 1.79; Cina: min 2.01; India: 2.10 dari skala 1-5). Kajian juga mendapati lelaki lebih banyak terlibat dalam politik berbanding perempuan (Lelaki: min 2.07; perempuan: min 1.73 dari skala 1-5) dan mereka yang berusia 30an ke atas lebih banyak terlibat dalam politik berbanding golongan yang lebih muda. Tiada perbezaan ketara dari segi penglibatan politik dalam kalangan mereka yang berpendapatan tinggi atau rendah dan berpendidikan tinggi atau rendah. 
Kebanyakan responden menunjukkan minat yang sederhana terhadap politik (Nilai min 3.22 dari skala 1-5), sikap yang agak negatif terhadap politik terutama dari segi ketelusan dan keadilan (nilai min 2.55 dari skala 1-5), penggunaan media yang sederhana bagi surat khabar (nilai min 3.31 dari skala 1-5) televisyen (nilai min 3.22 dari skala 1-5), Internet (nilai min 2.93 dari skala 1-5) dan agak rendah bagi radio (nilai min 2.26 dari skala 1-5). Mereka juga menunjukkan tahap pengetahuan politik yang sederhana (kebanyakan boleh menjawab lima dari sepuluh soalan yang dikemukakan) dan tahap perbincangan interpersonal tentang politik, yang juga agak sederhana (nilai min 2.06 dari skala 1-4). Hasil kajian juga menunjukkan tahap penglibatan politik yang masih rendah (nilai min 1.90 dari skala 1-5) terutama dari segi menghadiri mesyuarat politik, menderma untuk parti politik dan menjadi ahli berdaftar dalam parti politik. Walau bagaimanapun, item mengundi dalam pilihanraya mencatatkan nilai min yang tinggi iaitu 3.39, sekaligus membuktikan kurangnya penyertaan dan budaya berpolitik secara menyeluruh dalam masyarakat Pulau Pinang, cuma terhad dan fokus kepada aktiviti mengundi semasa pilihanraya sahaja.

Seterusnya bagi mengetahui faktor yang paling mempengaruhi penglibatan politik dalam kalangan responden di Malaysia, pengkaji menggunakan Ujian Hierarchical Regression. Berdasarkan nilai beta dalam Jadual 1, dapat dilihat bahawa umur, penggunaan televisyen, surat khabar, radio, Internet dan sikap terhadap politik tidak mempengaruhi penglibatan politik. Walau bagaimanapun faktor perbincangan interpersonal tentang politik mempengaruhi penglibatan dalam politik $\beta=0.532, p=0.001$. Seterusnya, minat dan pengetahuan umum terhadap politik didapati mempengaruhi penglibatan dalam politik $\beta=0.106, p=0.05$ dan $\beta=0.094, p=0.05$. Ini membuktikan bahawa mereka yang sering berbincang tentang politik bersama rakan-rakan dan keluarga, mempunyai minat dan tahap pengetahuan umum yang tinggi dalam politik, akan lebih melibatkan diri dalam politik seperti dengan berkempen untuk parti politik yang disokong dan menderma untuk parti politik.

Jadual 1 Ringkasan analisis hierarchical regression.

\begin{tabular}{|c|c|c|c|}
\hline & $\boldsymbol{R}$ & Beta & $\mathbf{R}^{2}$ Change \\
\hline $\begin{array}{l}\text { Faktor Demografi } \\
\bullet \quad \text { Umur }\end{array}$ & 0.178 & 0.017 & 0.032 \\
\hline $\begin{array}{l}\text { Faktor Perbincangan } \\
\text { - Perbincangan interpersonal } \\
\text { mengenai politik }\end{array}$ & 0.739 & $0.532 * *$ & 51.4 \\
\hline $\begin{array}{l}\text { Faktor Media Massa } \\
\text { - } \quad \text { Surat Khabar } \\
\text { - Internet } \\
\text { - Televisyen } \\
\text { - } \quad \text { Radio }\end{array}$ & 0.767 & $\begin{array}{l}0.081 \\
0.080 \\
-0.05 \\
0.090\end{array}$ & 0.043 \\
\hline 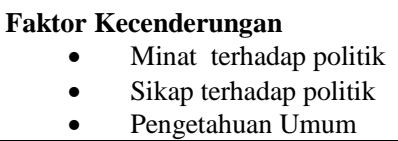 & 0.776 & $\begin{array}{l}0.106 * \\
0.025 \\
0.094 *\end{array}$ & 0.014 \\
\hline
\end{tabular}

Seterusnya bagi menguji Model Differential Gains, iaitu untuk menguji kesan faktor perantara perbincangan interpersonal terhadap hubungan antara pemboleh ubah bebas dan bersandar, maka beberapa siri ujian statistik dilakukan. Selaras dengan saranan Baron and Kenny (1986), ujian korelasi dilakukan telrebih dahulu bagi melihat hubungan antara pemboleh ubah bebas dan bersandar. Hasil ujian korelasi Pearson menunjukkan bahawa kesemua pemboleh ubah bersandar menunjukkan hubungan yang siknifikan dengan penglibatan politik. Umur $(\mathrm{r}=0.175, \mathrm{p}=0.000)$, minat terhadap politik $(\mathrm{r}=0.609, \mathrm{p}=0.000)$, sikap terhadap politik $(\mathrm{r}=0.130, \mathrm{p}=0.005)$, pengetahuan tentang politik $(\mathrm{r}=0.513, \mathrm{p}=0.000)$, penggunaan surat khabar $(\mathrm{r}=0.568, \mathrm{p}=0.000)$, televisyen $(\mathrm{r}=0.483, \mathrm{p}=0.000)$, radio $(\mathrm{r}=0.367$, $\mathrm{p}=0.000)$, Internet $(\mathrm{r}=0.488, \mathrm{p}=0.000)$ dan perbincangan interpersonal tentang politik $(\mathrm{r}=0.734, \mathrm{p}=0.000)$ menunjukkan korelasi yang siknikan dengan penglibatan politik.

Seterusnya Ujian Regresi Berganda digunakan untuk menilai kesan faktor umur, minat, sikap, pengetahuan, penggunaan akhbar, televisyen, radio dan Internet terhadap penglibatan politik. Hasil kajian menunjukkan umur $(\beta=0.130$, $p=0.001)$, minat terhadap politik $(\beta=0.284, p=0.000)$, pengetahuan tentang politik $(\beta=0.179, p=0.000)$, penggunaan surat khabar $(\beta=0.155, p=0.020)$ dan Internet $(\beta=0.111$, $\mathrm{p}=0.047)$ menunjukkan hubungan yang siknifikan dengan penglibatan politik kecuali faktor sikap terhadap politik $(\beta=0.056, \mathrm{p}=0.167)$, televisyen $(\beta=0.001, p=0.986)$ dan radio $(\beta=0.080, p=0.067)$. Walau bagaimanapun apabila faktor perbincangan interpersonal dimasukkan di dalam model, cuma faktor pengetahuan $(\beta=0.080, \mathrm{p}=0.070)$, penggunaan akhbar $(\beta=0.069, \mathrm{p}=0.236)$ yang pada awalnya siknifikan, didapati menjadi tidak siknifikan. Malah faktor penggunaan radio yang pada awalnya tidak signifikan, tetapi menjadi signifikan $(\beta=0.083$, $\mathrm{p}=0.028$ ) selepas pemboleh ubah perbincangan interpersonal dimasukkan. Keseluruhannya didapati bahawa $59.3 \%$ varian dari penglibatan politik disumbang oleh pemboleh ubah-pemboleh ubah bersandar yang dikaji.

Ini jelas menunjukkan bahawa faktor perbincangan interpersonal memainkan peranan perantara yang cukup penting antara pengetahuan tentang politik, penggunaan akhbar dan radio dengan penglibatan politik. Dalam kata lain individu yang mempunyai pengetahuan yang tinggi dalam politik dan sering membaca akhbar dan mendengar radio tentang isu-isu semasa akan cenderung berbincang secara interpersonal bersama rakan-rakan tentang perkara ini. Ini seterusnya akan meningkatkan penglibatan politik mereka. 


\subsection{RUMUSAN}

Amat menarik perhatian apabila hasil kajian menunjukkan bahawa kaum Melayu menunjukkan tahap penglibatan politik yang paling rendah berbanding kaum-kaum lain di Pulau Pinang. Harus diingat bahawa kajian ini dijalankan di luar musim pilihanraya, maka jelas mengambarkan bentuk penglibatan politik yang tidak konsisten terutama dalam kalangan kaum Melayu. Semangat, jiwa dan budaya berpolitik cuma berlaku semasa pilihanraya. Di waktu senggang yang lain, masyarakat Melayu terutamanya, agak pasif dalam melibatkan diri dalam sistem demokrasi. Kaum Cina dan India walau bagaimanapun, menunjukkan tahap penyertaan politik yang lebih baik dan konsisten, yang mungkin memperlihatkan kesungguhan mereka melakukan perubahan.

Seterusnya kajian cuba mengenalpasti faktor-faktor dalaman dan luaran yang mempengaruhi penglibatan politik masyarakat Pulau Pinang. Berdasarkan analisa Ujian Hierarchical Regression menunjukkan bahawa perbincangan interpersonal tentang politik amat mempengaruhi tahap penglibatan politik diikuti faktor minat dan pengetahuan umum tentang politik. Ini jelas menunjukkan kepentingan komunikasi interpersonal berbanding media massa dalam menggalakkan penglibatan politik seseorang warganegara. Pun begitu, harus diingat bahawa dapatan kajian ini diperolehi di luar waktu pilihanraya. Sekiranya kajian ini dijalankan sewaktu pilihanraya dijalankan, mungkin faktor-faktor lain seperti penggunaan media massa, sikap dan umur akan turut mempengaruhi tahap penglibatan politik. Jika tidak kerana keyakinan kepada media massa, mana mungkin kerajaan sanggup membelanjakan hampir RM531juta dari Januari- Jun 2013 bagi tujuan periklanan media elektronik dan media cetak dalam usaha menghadapi PRU-13 (www.themalaymailonline.com) walaupun percaturan tersebut turut mengundang risiko lain. Kajian akan datang mungkin perlu dijalankan dalam dan di luar musim pilihanraya bagi menilai sama ada wujud perbezaan dapatan antara kedua-dua tempoh tersebut.

Seterusnya dapatan dari beberapa siri analisis lanjutan membuktikan bahawa faktor perbincangan interpersonal tentang politik memainkan peranan perantara yang cukup penting dalam hubungan antara pendedahan terhadap berita akhbar dan radio dan penglibatan politik. Dapatan yang diperoleh ini juga selaras dengan model Differential Gains yang mengandaikan bahawa media massa tidak selalu mempunyai pengaruh secara langsung terhadap penglibatan mereka dalam politik. Sebaliknya kesan mesej media massa terhadap penglibatan politik bergantung pada perbincangan interpersonal mengenai politik dengan orang lain. Individu yang menerima maklumat tentang politik dari media massa dan membincangkannya dengan keluarga dan rakan-rakan akan lebih komited and beriltizam dalam politik berbanding mereka yang berdiam diri dan tidak berkongsi pandangan mereka dengan individu terdekat. Dalam konteks ini, maklumat yang diperolehi dari media masa digunakan sebagai bahan perbincangan, perbahasan dan sindiran politik bersama rakan-rakan.

Senario yang sama dilabelkan oleh Matei dan Ball-Rokeach (2003) sebagai "storytelling-neighbourhood" bagi mengambarkan kewujudan jaringan komuniti yang kuat yang dibina bersandarkan penggunaan media terutamanya media sosial online dan komunikasi interpersonal dalam masyarakat setempat. Senario storytelling-neighbourhood yang biasanya dilihat di kedai kopi, kedai mamak, pusat komuniti, pasar atau di kawasan kejiranan di Malaysia walaupun tampak santai tetapi mampu meningkatkan penglibatan politik masyarakat kerana melalui wadah ini, masyarakat dapat berbincang kebimbangan, dilemma, harapan dan cita-cita mereka, yang seterusnya mendorong mereka untuk bersama-sama terlibat aktif dalam sistem politik negara.

Dalam konteks situasi politik di Pulau Pinang, jelas menunjukkan bahawa media massa tidak lagi berpengaruh secara terus dalam meningkatkan penglibatan politik rakyat negeri tersebut. Kekesalan dan kejengkelan terhadap media yang menjadi tunggangan parti pemerintah, dapat dilihat dari kritikan keras Zaharom (1992) yang mengatakan bahawa pemerintah dan institusi pemerintah kerap menjadi pelakon utama dalam media dan peranan media hanya sebagai tukang urut bagi agensi-agensi kerajaan. Mungkin inilah label yang diberikan oleh rakyat Pulau Pinang menyebabkan apa yang disampaikan media tidak lagi diterima bulat-bulat, sebalik dibincang, dikupas, dianalisis dan perdebatkan secara panjang lebar dalam perbincangan santai di kedai kopi, pasar dan di pelantar kayu di tepi rumah. Hasil perbincangan kedai kopi inilah yang lebih mendorong masyarakat untuk keluar mengundi, mendaftar sebagai ahli parti politik, bersuara lantang kepada Ahli Dewan Undangan Negeri dan sebagainya.

Pengaruh komunikasi interpersonal ini selaras dengan hasil kajian oleh Samsudin A Rahim (2010) dalam kalangan 8823 belia yang berumur 21-40 tahun menunjukkan kepercayaan terhadap maklumat yang disampaikan oleh kawan-kawan menpengaruhi kepuasan mereka terhadap keputusan pilihanraya umum ke-12 yang lebih memihak kepada parti pembangkang. Penemuan kajian ini juga membuktikan mengapa sesetengah kempen atau propaganda politik yang disampaikan melalui media gagal atau kurang berkesan. Hal ini berlaku kerana rakyat biasanya menggunakan maklumat atau propaganda yang disampaikan melalui media massa untuk berbincang dengan keluarga dan rakan-rakan yang lebih dekat dan dipercayai. Mereka menganalisa, mempersoalkan dan membuat rumusan tentang maklumat politik yang diperolehi dari televisyen, surat khabar, berita radio dan Internet bersama keluarga dan rakan-rakan sebelum akhirnya membuat keputusan yang biasanya lebih cenderung mengikut hasil perbincangan bersama orang yang paling dekat dan dipercayai oleh mereka iaitu rakanrakan dan keluarga terdekat.

Selain faktor perbincangan interpersonal, faktor lain iaitu minat dan pengetahuan umum turut dilihat berperanan penting dalam meningkatkan penglibatan politik. Hal ini selaras seperti yang dinyatakan oleh Denny dan Doyle (2008), dan Kalyango (2009), yang mendapati golongan yang mempunyai minat yang tinggi serta mempunyai maklumat yang lebih banyak mengenai isu politik akan menunjukkan penglibatan yang lebih tinggi dalam politik.

Hal ini disokong oleh Zaller (dalam Skipworth, 2009), mereka yang terdedah kepada mesej media dan memahami maklumat tersebut menunjukkan kesedaran politik yang lebih tinggi. Menurut Scheufele (2002), pengetahuan berkenaan politik mengupayakan rakyat untuk membuat keputusan dan meningkatkan pemahaman mereka berkenaan proses politik. Oleh yang demikian, boleh dinyatakan bahawa sememangnya pengetahuan umum seseorang dalam isu politik dan isu semasa memainkan peranan dalam mempengaruhi tindakan seseorang dalam politik.

Terdapat beberapa limitasi dalam kajian ini. Limitasi yang pertama adalah kajian ini menggunakan kaedah persampelan pelbagai tahap (multi-stage-cluster sampling) dan convenience yang hanya melibatkan beberapa kawasan Dewan Undangan Negeri di Daerah Barat Daya dan Timur Laut Pulau Pinang yang dipilih. Bagi kajian akan datang, pengkaji menyarankan agar responden dipilih daripada setiap kawasan tempat kajian agar boleh digeneralisasikan kepada keseluruhan kawasan atau mewakili populasi rakyat yang lebih besar.

Selain itu, kajian ini melibatkan responden dari kategori umur yang luas iaitu bermula dua puluh satu tahun ke atas. Bagi kajian pada masa hadapan, pengkaji mencadangkan agar sampel dapat distratifikasikan mengikut beberapa kategori demografi berdasarkan umur atau gender tertentu. Penyelidik misalnya boleh mengkaji perbezaan tahap penglibatan politik, minat, penggunaan media sosial bagi tujuan 
menyampaikan berita politik antara golongan belia, etnik dan golongan berumur atau antara golongan wanita dan lelaki malah antara masyarakat di luar bandar dan bandar agar dapatan yang diperolehi lebih bersifat fokus dan menarik.

Di samping itu, pengukuran penglibatan politik hanya mengambil kira aktiviti yang bersifat lazim seperti mengedar bahan kempen kepada rakan-rakan dan tidak mengambilkira aktiviti yang tidak lazim seperti melakukan demonstrasi jalanan dan menandatangani petisyen. Kajian akan datang perlu mempertimbangkan pengukuran yang lebih jitu dan mencakupi pelbagai komponen dalam konstruk penglibatan politik. Begitu juga dengan perkembangan media sosial yang begitu pantas dalam kalangan rakyat, perkongsian pandangan politik kini diperluaskan dalam pelbagai platform siber seperti Facebook, Twitter, blog dan forum politik. Item-item ini perlu dimasukkan dalam instrumen pengukuran perbincangan interpersonal dalam politik. Platform media sosial yang dikatakan kurang peribadi kerana pemilik sebenar akaun media sosial tidak diketahui atau sentiasa boleh dikaburi, mungkin mendorong kepada lontaran kritikan keras dalam perbincangan sebegini berbanding perbincangan yang dilakukan secara bersemuka.

Kajian ini juga hanya tertumpu kepada faktor-faktor mikro yang agak terhad iaitu minat, pengetahuan, sikap, pendedahan media dan perbincangan interpersonal. Kajian akan datang perlu turut mengambilkira faktor-faktor makro seperti isu sosial dan politik semasa yang mungkin menyebabkan peningkatan tahap penglibatan politik kumpulan etnik tertentu misalnya isu tanggapan ketidakadilan dan peminggiran kaum dalam pemberian biasiswa kerajaan, kontrak kerajaan dan swasta dan peluang mendapatkan pekerjaan dalam organisasi yang dikuasai ethnik tertentu. Begitu juga isu-isu semasa seperti isu penggunaan kalimah Allah dalam Bible Bahasa Malaysia, isu GST dan 1MDB dilihat turut memanaskan situasi politik Malaysia yang mungkin secara langsung atau tidak langsung turut mempengaruhi tahap penglibatan politik kaum yang terlibat.

Jelasnya, dapatan kajian ini yang konsisten dengan Model Differential Gain menunjukkan masyarakat di Pulau Pinang semakin berani dan telus meluahkan pendapat mereka dalam pelbagai interaksi perbincangan interpersonal kerana merasakan inilah pandangan majoriti. Inilah yang disebut oleh Noelle Neumann (1991) dalam Teori Spiral of Silence yang mengatakan bahawa individu akan lebih terdorong untuk melahirkan pandangan politiknya secara terbuka, apabila ia merasakan majoriti masyarakat di sekelilingnya turut berpandangan sedemikian. Perbincangan politik secara terbuka dan yakin, sama ada dalam bentuk bersemuka atau melalui media siber, secara tidak langsung telah membawa kepada peningkatan jumlah pengundi yang keluar mengundi di Pulau Pinang, malah mendorong kepada perubahan suara rakyat dari segi pemilihan parti yang memerintah.

Akhirnya, kajian akan datang, dilihat perlu mengembangkan Model Differential Gain dengan menilai semula konstruk pengukuran perbincangan interpersonal. Apakah bentuk perbincangan interpersonal yang paling efektif? Adakah perbincangan santai atau perbincangan serius, lebih mendorong kepada penglibatan politik yang aktif? Berkaitan dengan ini, Teori Impak Sosial (Latane, 1981) mengariskan bahawa impak perbincangan interpersonal bergantung kepada tiga faktor penting iaitu kekuatan sumber, kedekatan hubungan sumber dan akhirnya jumlah sumber perbincangan. Dalam kata lain, perbincangan interpersonal akan lebih efektif apabila ia melibatkan interaksi dengan sumber yang berpengaruh, sumber yang rapat dan jumlah interaksi interpersonal dengan pelbagai sumber. Gabungan pemboleh ubah-pemboleh ubah dalam Teori Impak Sosial ini ke dalam Model Differential Gain dilihat mampu menambahbaik model ini.

\section{Rujukan}

Ahmad, N. S. Y., Syed, M. D. \& Sani, M. A. (2017). Proclivity of Political Participation Among Wakaidesu Japanese. Pertanika Journal of Social Sciences \& Humanities, 25, 123-138

Azmah Abdul Manaf. (2001). Sejarah Sosial Masyarakat Malaysia. Kuala Lumpur: Utusan Publications \& Distributors Sdn Bhd.

Barnes, S. H., \& Kaase, M. (1979). Political Action: Mass Participation in Five Western Democracies. London: Sage.

Baron, R. M., \& Kenny, D. A. (1986). The Moderator-Mediator Variable Distinction in Social Psychological Research: Conceptual, Strategic, and Statistical Considerations. Journal of Personality and Social Psychology, 51(6), 1173-1182

Chandra Muzaffar \& Syamsuddin, Harris (1989). The Barisan 2/3 Majority: Why the Opposition Failed. Dalam Challenges and Choices in Malaysia Politics and Society. Penang: Aliran Monthly.

Conway, M. M. (1991). Political Participation in The United State (2nd ed.). Washington, D.C: Congressional Quarterly Inc.

Denny, K., \& Doyle, O. (2008). Political Interest, Cognitive Ability and Personality: Determinants of Voter Turnout in Britain. British Journal of Political Science, 38, 291-310.

Department of Statistics Malaysia. Diakses 11/8/2017 dari https://www.dosm.gov.my.

Dermody, J., Hanmer, L.S., \& Scullion, R. (2008). Young People and Voting Behaviour: Alienated Youth and (or) an Interested and Critical Citizenry. European Journal of Marketing, 44(3/4), 421-435.

Deth, J.W. (2000). Interesting but Irrelevant: Social Capital and the Saliency of Politics in Western Europe. European Journal of Political Research, 37(22), 115-147. Durrishah Idrus, Hamidah Ab. Rahman, Husain Mahmood, Ishak Mad Shah \& Norashikin Mahmud (2004). Kajian Sikap Golongan Berpotensi terhadap Penyertaan dalam Proses Pilihanraya: Satu Kajian Kes di Negeri Johor. Laporan Penyelidikan. Diakses 14/7/2017 dari http://eprints.utm.my/2764/.

Eveland, W.P., \& Scheufele, D.A. (2000). Connecting News Media Use with Gaps in Knowledge and Participation. Political Communication, 17(3), 215-237.

Fatimah Akmal \& Ali Salman (2015). Partisipasi Politik Secara Online Melalui Ruang Demokrasi Maklumat Media Baru. Jurnal Komunikasi, 31 (1), 81-100

Fatimi, H., Zulkanain, A. R., Arbaiyyah, M. N., \& Mohd Roslan, M. N. (2016) Hak Asasi Manusia Dan Penglibatan Wanita Dalam Politik di Malaysia. Jurnal alTamaddun, 11(1), 17-33

Reichert, F., \& Print, M. (2017). Mediated and Moderated Effects of Political Communication on Civic Participation. Information, Communication \& Society, 20(8), $1162-1184$

Hamdan Adnan. (1995). Pendapat Umum. Kuala Lumpur: Dewan Bahasa dan Pustaka.

Hasmah Zainuddin \& Yuana King. (2006). Peranan Akhbar dan Maklum Balas Sosial: Berita Jenayah Akhbar Harian Metro . Diakses 1/3/2016 dari http://www.scribd.com/doc/18763750/Media-Massa

Henn, M., Weinstein, M., \& Hodgkinson, S. (2007). Social Capital and Political Participation: Understanding the Dynamics of Young People's Political Disengagement in Contemporary Britain. Social Policy and Society, 6(4), 467-479.

Hilley, J. (2001). Malaysia: Mahathirism, Hegemony and the New Opposition. London, New York: Zed Books.

Huntington, S. P., \& Joan M.Nelson. (1976). No Easy Choice: Political Participation in Developing Countries. Cambridge: Harvard University Press.

Junaidi Awang Besar. (2012). Persepsi Politik dan Trend Pengundian di Kawasan Dewan Undangan Negeri (DUN) Permatang Pasir, Pulau Pinang. Malaysia Journal of Society and Space, $8,61-70$

Junaidi Awang Besar. (2017). Tren Pengundian dalam Pilihanraya Umum Malaysia ke-13. e-Bangi: Journal of Social Sciences and Humanities, 12 (2), 126-149.

Kalyango, J. Y. (2009). Political News Use and Democratic Support: A Study of Uganda's Radio Impact. Journal of Radio and Audio Media 16(2), 200-215.

Latane, B. (1981). The Psychology of Social Impact: American Psychologist, 36, 343-365.

Lammie, K. E. (2009). Young Adults and A Model for Political Participation. Kertas dibentangkan di International Communication Association, New York City. 
Lemert, J. (1992). Effective Public Opinion. Dalam Public Opinion, the Press, and Public Policy, ed. Kennamer, J.D., 41-61. Westport, CT: Praeger.

Lin, J. H. (2016). Differential Gain in SNSs: Effects of Active vs. Passive Facebook Political Participation on Offline Political Participation and Voting Behavior among First-Time and Experienced Voters. Asian Journal of Communication, 26(3), 278-297

March, J. G. (1962). The Business Firm As Political Coalition. Journal of Politics, 24, 662-678

Matei, S., \& Ball-Rokeach, S. J. (2003). The Internet in the Communication Infrastructure of Urban Residential Communities: Micro-or Mesolinkage. Journal of Communication, 53, 642-657.

Mayes, B. T., \& Allen, R. W. (1977). Towards Definition of Organisational Politics. Academy of Management Review, 2, 672-678.

McLeod, J.M., Scheufele, D.A., \& Moy, P. (1999). Community, Communication, and Participation: The Role of Mass Media and Interpersonal Discussion in Local Political Participation. Political Communication, 16, 315-336.

Michael. X., \& Carpini, D. (1999). The Transformation of Civic Life. Kertas dibentangkan di konferen di Middle Tennessee State University, Murfreesboro \& Nashville, Tennessee.

Miller, J. M., \& Rahn, W. M. (2002). Identity-Based Feelings, Beliefs and Actions: How Being Influences Doing. Kertas dibentangkan pada 25th Annual Scientific Meeting of the ISPP, Berlin.

Mohd Faisal Syam Abdol Hazis, Nielson Lian Mersot \& Ahi Sarok. (2002). Tingkahlaku Pengundian dalam Pilihanraya Parlimen Sarawak. Kota Samarahan: UNIMAS.

Mohamad Sahari Nordin. (2001). Experiment on Approaches to Knowledge Construction. KualaLumpur: IIUM Press.

National Youth Survey. Merdeka Center for Opinion Research (2007). Diakses 12/7/2016 dari http://asiafoundation.org/resources/pdfs/MYsurveyfindeng.pdf

Nisbet, M. C., \& Scheufele, D. A. (2004). Political Talk As A Catalyst Of Online Citizenship. Journalism and Mass Media Quarterly, 81, 4, 877-896.

Noelle-Neumann, E. (1991). The Theory of Public Opinion: The Concept of The Spiral of Silence. In J. A. Anderson (Ed.), Communication Yearbook, 14 , 256-287. Newbury Park: Sage

Parry, G., Moyser, G., \& Day. N. (1992). Political Participation and Democracy in Britian. Cambridge: Cambridge University Press.

Phelps, E. (2005). Young Voters at the 2005 Britain General Election. The Political Quarterly, 76(4), 482-87.

Pojman, L. P. (1999). The Theory of Knowledge: Classical and Contemporary Readings. Belmont, CA: Wadsworth Publishing Company.

Rea, L., \& Parker, R. (1997). Designing and Conducting Survey Research: A Comprehensive Guide (2nd Ed.). San Francisco: Jossey-Bass.

Robinson, J.P., \& Levy, M.R. (1986). Interpersonal Communication and News Comprehension. Public Opinion Quarterly, 50, 160-175.

Rojas, H., \& Puig-i-Abril, E. (2009). Mobilizers Mobilized: Information, Expression, Mobilization and Participation in the Digital Age. Journal of ComputerMediated Communication, 14, 902-927.

Rosenberg, M.J., \& Hovland, C.I. (1960), Cognitive, Affective, and Behavioral Components of Attitudes. Dalam Hovland, C.I. dan Rosenberg, M.J. (Eds), Attitude Organization and Change: An Analysis of Consistency among Attitude Components. pp. 1-14. New Haven: Yale University Press.

Ruedin, D. (2007). Testing Milbrath's 1965 Framework of Political Participation: Institutions and Social Capital. Diakses 1/7/2017 dari https://druedin.files.wordpress.com/2012/08/43-167-1-pb.pdf.

Ruhanie Ahmad (2009). Realiti kebebasan akhbar di Malaysia. Diakses 23/7/2016 dari http://www.utusan.com.my/utusan /info

Salman, A., Samsudin, A. R., \& Yusuf, F. (2017). Civic and Political Participation: A Study of Marginalised and Mainstream Youth in Malaysia. Pertanika Journal of Social Sciences \& Humanities, 25, 67-76

Samsudin A. Rahim. (2010). Media, Demokrasi dan Generasi Muda: Analisis Keputusan Pilihanraya Umum Ke-12. Jurnal Komunikasi, 26(2), 1-15.

Sarnoff, I. (1960). Psychoanalytic Theory and Social Attitudes. Public Opinion Quarterly, 24, 251-279.

Scheufele, D. A. (2001). Democracy For Some? How Political Talk Both Informs and Polarizes the Electorate. Dalam Communication and U.S. Elections: New Agendas, eds. Hart, R.P. dan Shaw, D., 19-32. Lanham, MD: Rowman and Littlefield Publishers.

Scheufele, D. A. (2002). Examining Differential Gains From Mass Media and Their Implications for Participatory Behaviour. Communication Research, 29(1), 46-65.

Schudson, M. (1997). Why Conversation is Not the Soul of Democracy. Critical Studies in Mass Communication, 14, 297-309

Shani, D. (2008). Doubts About the Role of Formative Events in Developing Political Interest. Kertas dibentangkan di American Political Science Association, 2008 Annual Meeting.

Skipworth, S.A. (2009). A Differential Effect of Media on Political Attitudes of Younger and Older Adults. Kertas dibentangkan di Southern Political Science Association, 2009 Annual Meeting.

Syed Arabi Idid \& Shafizan Mohamed. (2006). Analysing Media Effects: The Third-Person Effect on Party Members. Dalam Mass Media Diversity in Changing Times, eds. Mohamad Md. Yusoff, Kamaliah Siarap, Azman Azwan Azmawati, Muhammad Hatta Muhammad Tabut, dan Juliana Abdul Wahab, Pulau Pinang: USM.

Verba, S., \& Nie, N. H. (1972). Participation In America. Chicago: The University of Chicago Press.

Wan Asna Wan Mohd Nor, Salfarina Abdul Gapor, Mohamad Zaini Abu Bakar \& Zainon Haron. (2011). Some Socio-Demographic Determinants of Political Participation. 2011 International Conference on Humanities, Society and Culture. Singapore: IACSIT Press.

Wan Rohila Ganti Wan Abdu Ghapar. (2008). Political Culture and Political Participation of the Electorates in Kuala Berang, Terenganu: A Post-Election Survey Tesis Sarjana. Universiti Islam Antarabangsa

White, C. (2003). Selling Politics To Young People. Young Consumers: Insight And Ideas For Responsible Marketers, 4(2), 41-46.

White, C., Bruce, S., \& Ritchie, J. (2000). Young People's Politics: Political Interest and Engagement amongst 14- to 24-Year-Olds. New York: Joseph Rowntree Foundation.

Willnat, L., Wong, W. J., Tamam, E., \& Aw, A. (2013). Online Media and Political Participation: The Case of Malaysia. Mass Communication and Society, 16, 557585

Zaharom, N. (1992). Negara dan Media: Kaitan yang Membimbangkan. Di dalam Mohd Dhari Othman. Pasca Sidang. Seminar Penyelidikan Komunikasi. UKM: Bangi.

Zawiyah, M. Z., Mohammad, A. Y., \& Izham, H. H. (2015). Civil Disobedience During Reformation Era. e-Bangi, 2, 187-194

World Press Freedom Index. Diakses 12/6/2016 dari https://rsf.org/en/ranking/2017?\#

www.astroawani.com. 4.1 juta rakyat Malaysia yang layak mengundi belum berdaftar sebagai pengundi Diakses 2/6/2016 dari http://www.astroawani.com/beritamalaysia/4-1-juta-rakyat-malaysia-yang-layak-mengundi-belum-berdaftar-sebagai-pengundi-spr-134351

www.spr.gov.my. Keputusan pilihanraya. Diakses 11/7/2016 dari http://spr.gov.my/index.php/component/content/article?layout=edit\&id=74=

www.straitstimes.com. GE2015: Voter turnout at 93.56 per cent, improves slightly from 2011 record low. Diakses 10/6/2016 dar www.straitstimes.com/politics/ge2015-voter-turnout-at-9356-per-cent-improves-slightly-from-2011-record-low.

www.dosm.gov.my. Statistics Malaysia Diakses

www.dosm.gov.my/v1/index.php?r=column/cone\&menu_id=dDM2enNvM09oTGtQemZPVzRTWENmZz09.

$12 / 5 / 2016$

www.thestar.com.my. Diakses 12/7/2016

www.nst.com.my Political parties race to register new and young voters. Diakses 15/2/2016 dari www.nst.com.my/nst/articles//Article

www.penang.gov.my. Diakses 19/6/2016

www.themalaysiainsider.com. Diakses 5/6/2016

www.themalaymailonline.com. Diakses 8/6/2016 